\title{
Biomarkers of acute lung injury: worth their salt?
}

\author{
Alastair G Proudfoot ${ }^{1,2+}$, Matthew Hind ${ }^{1,2+}$ and Mark JD Griffiths ${ }^{1,2^{*+}}$
}

\begin{abstract}
The validation of biomarkers has become a key goal of translational biomedical research. The purpose of this article is to discuss the role of biomarkers in the management of acute lung injury (ALI) and related research. Biomarkers should be sensitive and specific indicators of clinically important processes and should change in a relevant timeframe to affect recruitment to trials or clinical management. We do not believe that they necessarily need to reflect pathogenic processes. We critically examined current strategies used to identify biomarkers and which, owing to expedience, have been dominated by reanalysis of blood derived markers from large multicenter Phase 3 studies. Combining new and existing validated biomarkers with physiological and other data may add predictive power and facilitate the development of important aids to research and therapy.
\end{abstract}

\section{Introduction}

The syndrome acute lung injury (ALI) and its more severe counterpart acute respiratory distress syndrome (ARDS) are defined by radiographic and physiological changes that characterize patients with acute lung failure (Table 1) [1]. All age groups may be affected, although the syndrome has a higher incidence and mortality in older people. Across all ages the incidence is approximately 200,000 cases per year in the United States with a mortality of around 35\% [2]. Survivors face a long-term reduction in quality of life; for example, only $54 \%$ of survivors were able to return to work 12 months after hospital discharge [3].

The validation of biomarkers, for use in clinical trials and ultimately in practice, has become a central tenet of translational biomedical research [4]. The purpose of this article is to discuss the role of biomarkers in the management of ALI and related research. We shall not present a state of the art review of the field of all the biomarkers that have been investigated in this field, excellent examples of which have been produced recently [5,6]. Rather, we shall question current strategies to identify biomarkers and whether what has been achieved thus far has advanced the field.

\footnotetext{
* Correspondence: m.griffiths@imperial.ac.uk

† Contributed equally

${ }^{1}$ Royal Brompton \& Harefield NHS Foundation Trust, Adult Intensive Care

Unit, Sydney Street, London SW3 6NP, UK

Full list of author information is available at the end of the article
}

\section{The natural history of acute lung injury}

Regardless of the wide variety of insults that cause or contribute to the development of ALI, the response of the lung is largely stereotypic. A combination of tissue injury and inflammation affecting the gas exchange surface of the lung, the alveolar-capillary membrane, causes high permeability pulmonary edema. The presence of a protein-rich inflammatory exudate in the airspace impairs surfactant function [7]. The resulting collapse and consolidation of the lung causes profound hypoxemia because inflammatory mediators induce changes in the control of vascular tone that disable hypoxic pulmonary vasoconstriction [8]. Loss of pulmonary capillary surface area associated with localized lung destruction and occlusion of the vascular bed by intravascular thrombosis, increases the anatomical dead space, itself associated with a poor outcome [9], giving rise to carbon dioxide retention. Host factors, both inherited $[10,11]$ and acquired, influence individual susceptibility, (for example, excessive alcohol consumption predisposes, while diabetes mellitus protects) $[12,13]$. Precipitating causes or risk factors, which often "hunt in packs", either affect the lung directly (pneumonia, aspiration of stomach contents and thoracic trauma) or cause ALI indirectly through a systemic inflammatory response syndrome (SIRS) associated with multiple organ dysfunction, exemplified by severe sepsis and transfusion related ALI [14]. These causes, to a large part, determine the initial clinical course and outcome, but most patients subsequently require invasive
C Biomed Central

(c) 2011 Proudfoot et al; licensee BioMed Central Ltd. This is an Open Access article distributed under the terms of the Creative Commons Attribution License (http://creativecommons.org/licenses/by/2.0), which permits unrestricted use, distribution, and reproduction in any medium, provided the original work is properly cited. 
Table 1 NAECC definition of Acute Lung Injury (ALI) and Acute Respiratory Distress Syndrome (ARDS)[1]

\begin{tabular}{ccccc}
\hline & Timing & Oxygenation & Chest Radiograph & Exclusion of cardiogenic pulmonary oedema \\
\hline ALI & Acute & $\mathrm{PaO}_{2} / \mathrm{FiO} 2 \leq 300 \mathrm{mmHg}$ & Bilateral opacities consistent with & PAOP $\leq 18 \mathrm{mmHg}$ if measured or no clinical evidence of left \\
ARDS & or $40 \mathrm{kPa}$ & pulmonary oedema & atrial hypertension \\
& & $\mathrm{PaO}_{2} / \mathrm{FiO}_{2} \leq 200 \mathrm{mmHg}$ & & \\
& or $27 \mathrm{kPa}$ & &
\end{tabular}

$\mathrm{PaO}_{2} / \mathrm{FiO}_{2}$, arterial partial pressure of oxygen/inspired oxygen fraction; PAOP, pulmonary artery occlusion pressure

mechanical ventilation in an intensive care unit to maintain adequate gas exchange and often other organ supports.

While the development of pulmonary fibrosis in a patient with ALI predicts the requirement for prolonged respiratory support and a poor outcome [15], relatively little is known about the processes that determine the resolution of inflammation, injury and subsequent lung repair [16]. The consecutive three-phase pathological model of ALI (exudative, proliferative and fibrotic) is a gross over-simplification. Fibrosis is evident histologically as early as a week after the onset of the disorder [17] and procollagen III peptide, a precursor of collagen synthesis, is elevated in the broncho-alveolar lavage (BAL) fluid of ARDS patients at the time of tracheal intubation [18]. Indeed, not only is the injured lung known to be heterogeneously affected [19], it also seems likely from the examination of lavage samples from patients that these pathological processes coincide in the same lung region [20]. Similarly, while several proinflammatory mediators are also pro-fibrotic, distinct patterns of gene expression are associated with acute inflammation and fibrosis in the injured lung, suggesting that fibrosis is not simply an inevitable consequence of unresolved inflammation [21]. Indeed, current thinking

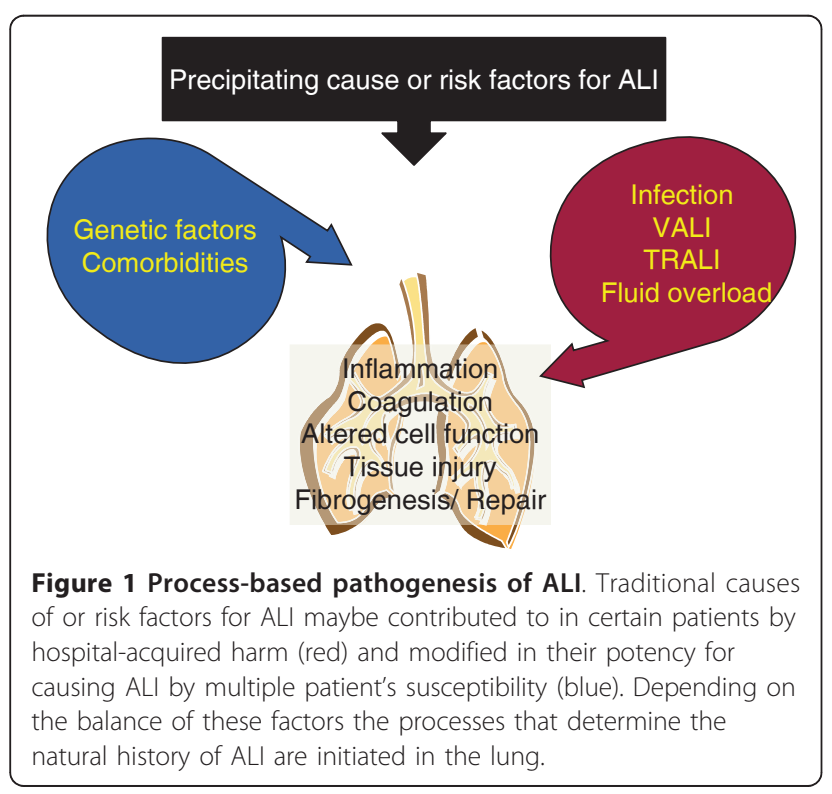

emphasizes the primary role of disordered epithelial repair, which may be contributed to by repeated or persistent injury and inflammation, in driving a pathological fibrotic response [22].

Despite years of concerted effort and very many clinical trials, a minority of which have been capable of producing a definitive result, there are no treatments (as opposed to modifications of organ support [23,24]) that improve the outcome of patients with ALI [25]. What has become evident, both in this field and in critical care in general, is the extent and importance of iatrogenic injury. Hence, half of ALI arises in patients who were subjected to mechanical ventilation for another reason: the four major culprits being mechanical ventilation that targets normal blood gas parameters, transfusion of blood products, excessive fluid resuscitation and hospital acquired pneumonia (Figure 1) [26-29]. Accordingly, recent epidemiological evidence suggests that targeting hospital acquired injury can halve the incidence of ARDS despite an increase in patients' severity of illness, the number of comorbidities and the prevalence of major ARDS risk factors [30].

Hence, studying patients with ALI is a challenge because the syndrome is the end result of an almost infinite variety of scenarios. These range from young fit patients with severe pneumonia or thoracic trauma to older patients who fail to recover from routine procedures, suffer complications, require respiratory support because of a combination of a chronic cardio-respiratory condition and hospital-acquired pneumonia, and ultimately develop ARDS on a ventilator. As a consequence, the water is muddied both by heterogeneity in the host and in the risk factors, and by the variety of other coincident processes. Furthermore, it is often difficult to define precisely when the syndrome started, which may have a dramatic effect on measured variables in cases where the condition changes rapidly. Finally, variable management regimens may contribute to patient heterogeneity, both in the face of clear evidence (for example, poor adherence to low tidal volume ventilation) [31] and where evidence is lacking (for example, in the use of adjuncts to respiratory support like prone positioning, inhaled nitric oxide and high frequency oscillation). Conversely, critically ill patients are closely monitored, physiological data are electronically stored and their 
clinical condition may paradoxically render them more amenable to undergoing invasive procedures.

\section{Why invest in biomarkers for ALI?}

Biomarkers are potentially useful as guides to clinical management and as research tools. In the clinical setting there is a high premium on biomarker data being easily and safely obtained within a timeframe that is relevant to the disease process (Table 2). For example, an indicator of poor prognosis that may encourage referral to a specialist center would need to be available within hours, whereas a marker of ventilator-associated lung injury (VALI) that was being used to fine-tune ventilator settings would have to be "turned around" within minutes. No biomarkers that are currently available have penetrated routine clinical practice with the possible exception of the use of procalcitonin (PCT) to diagnose sepsis in critically ill patients and to guide their antibiotic therapy [32]. Sepsis syndromes commonly both cause and complicate ALI; ventilator associated pneumonia in particular frequently exacerbates ALI causing diagnostic difficulty. Procalcitonin levels correlated with severe sepsis and bacteraemia [33], but did not consistently differentiate survivors from non-survivors [34]. A PCT-based algorithm guiding initiation and duration of antibiotic therapy in critically ill patients with suspected bacterial infection was associated with a $23 \%$ relative reduction in antibiotic exposure with no significant increase in mortality [32]. Aside from this role in limiting antibiotic exposure, a recent review of the role of PCT in diagnosing ventilator associated pneumonia concluded that the biomarker showed good specificity but low sensitivity [35].

Clinical research in ALI has used biomarkers as surrogate outcomes for early Phase 2 studies and may in the future be valuable in categorizing patients into subgroups that are predicted to be most likely to benefit from particular interventions. For example, in the single-centre BALTI 1 study 40 patients with ALI were enrolled to demonstrate the ability of seven days of treatment with intravenous salbutamol to decrease extravascular lung water measured by the single indicator transpulmonary thermodilution method (PiCCO, Pulsion Medical Systems, Munich, Germany) [36]. The resolution of pulmonary edema is central to recovery

\section{Table 2 Proposed characteristics of an ideal biomarker for acute lung injury}

Measurement is safe and feasible in the critically ill

Sensitive, reproducible and specific

Timely

Modified by an effective intervention to change the target outcome of interest from ALI as it entails defervescence of air space inflammation and restoration of a functioning alveolar-capillary membrane. Accordingly, elevated extravascular lung water measured using this technique early in the course of ALI/ARDS, particularly if indexed to predicted body weight, was associated with a poor outcome [37-39]. The initial ratio of $\mathrm{PaO}_{2} / \mathrm{FiO}_{2}$ was reported to be lower in non-survivors $[9,40-42]$ and predicted mortality in univariate analyses $[9,40,42]$. In addition, in one large cohort study, $\mathrm{PaO}_{2} / \mathrm{FiO}_{2}$ ratio was an independent predictor of mortality [42]. However, this variable does not take into account the mode or even presence of mechanical ventilation and apart from measurements at the extremes of the spectrum, it is generally not considered to be a robust predictor of outcome in ALI. Hence, the use of a surrogate rather than a clinical end-point, such as ventilator-free days or intensive care unit length of stay, decreased the recruitment target to what was achievable for a single center. However, in hindsight it is arguable whether this positive result then justified the investment in two Phase 3 large multicenter trials, which failed to show a survival benefit from using both inhaled and intravenous formulations of short-acting beta agonists [25].

The use of biomarkers to refine patient populations, such that clinical trials will be most likely to provide a definitive answer requiring the fewest patients, is particularly appealing for application to research involving patients with a heterogeneous syndrome like ALI. This could be beneficial by helping to characterize either a group of patients with a high mortality where mortality is the primary outcome measure, or by identifying patients in whom a pathological process, which is targeted by an intervention, is particularly prominent.

\section{Characteristics of ideal biomarkers for ALI}

Proposed criteria for characterizing ideal biomarkers for ALI, most of which are self-explanatory are listed in Table 2. It has been argued that biomarkers should inform or, at least, relate to the disease pathogenesis [43]. We disagree for philosophical reasons. Why confuse elucidating mechanisms with the pragmatic business of identifying biomarkers? We prefer as wide a definition as possible; for example, the electrocardiograph has been one of the most useful biomarkers in medicine but not much can be learned about the pathogenesis of myocardial infarction through its study.

The current definition of ALI/ARDS is such that biomarkers of the established syndrome are largely redundant. An exception would be a biomarker that was specific to the pathological process described as diffuse alveolar damage. That is, a biomarker that could exclude patients from studies who fulfilled the diagnostic criteria but who essentially have a distinct disease, which may 
have a different natural history and specific treatment, for example, cardiogenic pulmonary oedema, eosinophilic pneumonia and pulmonary embolism. Most studies have attempted to correlate selected biomarkers with disease severity or death, which is potentially useful both clinically to help target resources and more expensive or invasive management strategies, and in helping to power research studies using mortality as the primary outcome.

We propose that the use of biomarkers in a complex syndrome like ALI is most likely to be effective when they are specific to an individual component or process that can be manipulated. One productive approach has been to measure plasma and BAL fluid levels of mediators as a reflection of systemic and pulmonary inflammation respectively. In samples from large multicenter trials elevated levels of mediators, like soluble tumor necrosis factor-alpha receptors (sTNFR) 1 and 2 [44], soluble intercellular adhesion molecule-1 [45], and interleukin (IL)-6 [23] were associated with adverse outcomes in patients with ALI. The limitations of this strategy are that these mediators have multiple effects, have no specificity to the lung and there is no convincing evidence that manipulating the inflammatory response benefits patients with ALI. Partly because of the realization that VALI plays a major part in the pathogenesis of ALI and, as a result, many large studies have been performed examining the effects of ventilator strategies, a lot has been learned about the responses of popular biomarkers in patients undergoing protective and standard ventilation [6]. Hence, circulating mediators of inflammation (sTNFR [45], IL-6, -8 and -10 [46]), indicators of epithelial cell injury (soluble advanced glycation end-product receptors (sRAGE)) [47] and surfactant protein-D [48]) and components of the coagulation system (protein- $\mathrm{C}$ and plasminogen activator inhibitor-1 [49]) have all been promoted as biomarkers of VALI. However, because the proposed mechanism, whereby VALI kills patients through the exacerbation of local injury and inflammation, the mediators of which then leak into the systemic circulation causing multiple organ dysfunction [50], it would be surprising if there was not considerable overlap between markers of VALI, tissue injury, inflammation and a poor prognosis. In other words, these biomarkers inevitably lack specificity for individual processes or outcomes.

More recently the power of combining clinical parameters with a panel of traditional biomarkers to predict mortality in patients with ALI using a variety of statistical techniques has been examined in the large datasets and sample stores resulting from ARDS Network studies $[51,52]$. In one of these studies [52], the six clinical predictors were: age, the underlying cause, APACHE III score, plateau pressure, number of organ failures, and alveolar-arterial difference in the partial pressure of oxygen measured at enrollment prior to randomization. Eight biomarkers were measured in baseline plasma samples from enrolled patients that reflected endothelial and epithelial injury, inflammation and coagulation. A "reduced model", including just the APACHE III score, age, SP-D, and IL-8, performed almost as well as that which included all parameters and biomarkers. However, the additional predictive value of the plasma biomarkers added to the clinical predictors alone was modest; thus, further work will be needed to test the value of these biomarkers over clinical predictors alone. Furthermore, while the inclusion of biomarker data into a model improved the accuracy of mortality prediction, the predicted risk of death for the patients who ultimately died remained lower than 50\%, suggesting that important contributors to mortality may not have been accounted for by the model [51].

\section{Model systems for biomarker development}

An alternative approach to examining clinical samples is to test the validity of existing or novel candidate biomarkers using models systems, in which the signal-tonoise ratio is likely to be more favorable and the time course of the biomarker's response can be more precisely determined (Figure 2). For this purpose, we believe that human models are likely to be more useful than animal models, despite the undoubted contribution of the latter to our understanding of the syndrome's pathogenesis $[53,54]$. For example, at the most basic level comparative proteomic analysis between BAL fluid from a patient and a mouse model of ALI identified only 21 homologous proteins [55].

For an example of a human model of ALI, one lung ventilation $(\mathrm{OLV})$, a technique required to facilitate lung resection surgery, has been exploited to investigate potential biomarkers of VALI $[56,57]$. One-lung ventilation may be a useful model of VALI because it is associated with a smaller lung volume available for ventilation, localized lung collapse or atelectasis and impaired oxygenation, resulting in exposure of the ventilated lung to volutrauma, repeated opening of collapsed airspaces (atelectotrauma), and a high inspired oxygen concentration. High tidal volume and airway pressure during OLV correlated with the development of ALI in patients undergoing lung resection \{Fernandez-Perez, 2009 \#1309 [58]; Licker, 2003 \#38; Jeon, 2009 \#532\} and the incidence of ALI after lung resection over a five-year period was lower, compared to an historical control group, after introduction of a protective OLV protocol [59]. In small prospective studies the use of low tidal volume OLV was associated with reduced biomarkers of pulmonary and systemic inflammation \{Michelet, 2006 \#4882; [60]\} Finally, in an observational prospective 


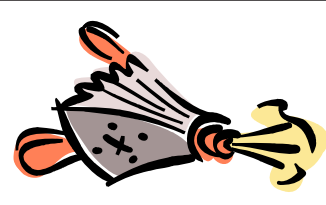

$>10 \mathrm{ml} / \mathrm{kg} \mathrm{pbw}$

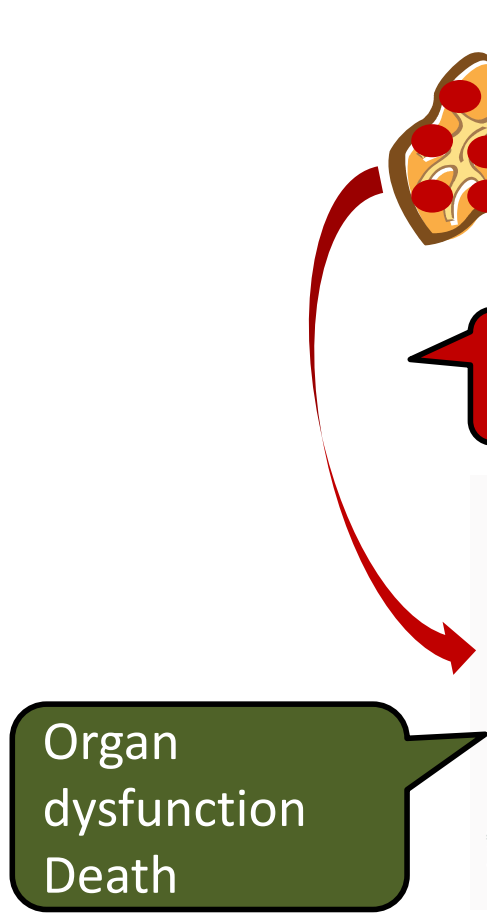

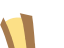
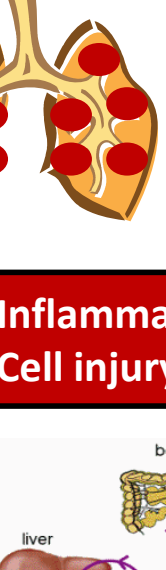

\&<smiles></smiles>
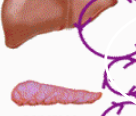<smiles></smiles>

Inflammation Cell injury

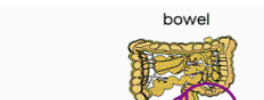

SIRS MODS

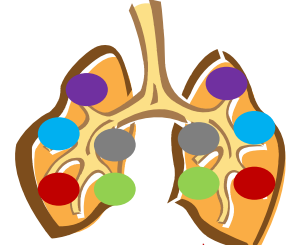

BAL

Breath

Imaging

Physiology

Figure 2 ALI biomarkers: Ventilator Induced Lung Injury experimental models and observational clinical studies. High tidal volume ventilation (tidal volume in excess of $10 \mathrm{ml} / \mathrm{kg}$ predicted body weight) may be used to induce lung injury in experimental models (left) but, through the overspill of inflammatory mediators into the circulation (biotrauma), multiple-organ dysfunction may follow. Biomarkers may be assayed directly from the lungs (black), from the circulation (red) or as indices of dysfunction related to other organs (green). In clinical studies (right), injured lungs are susceptible to damage even when gold standard mechanical ventilation (tidal volume $6 \mathrm{ml} / \mathrm{kg}$ predicted body weight) is used. However, in the presence of existing lung injury several processes are likely to be concurrent, both affecting the lungs directly (inflammation, tissue injury, coagulation, fibrosis) and indirectly from other affected organs (sepsis). Hence, the relationship between any biomarker and ventilator settings is likely to be obscured by multiple unknowns. BAL bronchoalveolar lavage, SIRS systemic inflammatory response syndrome, MODS multiple organ dysfunction syndrome.

study of 30 patients, exhaled breath condensate $\mathrm{pH}$ was reduced within minutes of starting OLV suggesting that it may represent a robust and direct means of sampling the milieu of the lung. While, in the clinical setting the effect on exhaled breath condensate $\mathrm{pH}$ of changing ventilator settings may be drowned by "noise" from coincident inflammatory processes in the lung, it may hold promise as a non-invasive real-time biomarker of VALI, despite the fact that the mechanism by which exhaled breath condensate acidification is poorly understood (Figure 2).

\section{Future directions}

Despite analyzing samples from large well-designed trials, there is no biomarker in current use that positively identifies patients with the classical histopathological appearances of diffuse alveolar damage, that predicts a poor outcome or that specifically identifies a pathological process [61].

We propose that future biomarker development be driven by novel therapies and support modalities. Biomarkers potentially combined with physiological and genomic data should be used to identify patient groups 
for research studies and individuals who are most likely to gain from targeted therapies. For example, novel extra-corporeal carbon dioxide removal $\left(\mathrm{ECCO}_{2} \mathrm{R}\right)$ systems that will make these techniques safer, cheaper and more readily available should stimulate the search for novel biomarkers for VALI. The demonstration that gold standard low tidal volume protective ventilation was associated with signs of over-distension on CT scanning, elevated plasma markers of inflammation and a plateau airway pressure greater than $28 \mathrm{cmH}_{2} \mathrm{O}$ in approximately a third of patients with ARDS provided a readily identifiable population on which the effectiveness of novel $\mathrm{ECCO}_{2} \mathrm{R}$ devices could be tested [62]. In a subsequent study, a group of patients with ARDS was identified by their having a plateau airway pressure greater than $28 \mathrm{cmH}_{2} \mathrm{O}$ and in whom low tidal volume ventilation was presumed to be causing significant VALI. For these patients a novel $\mathrm{ECCO}_{2} \mathrm{R}$ device (DeCap, Hemodec, Salerno, Italy) enabled the research team to decrease tidal volume, further targeting a plateau airway pressure of less than $25 \mathrm{cmH}_{2} \mathrm{O}$, which was associated with a lower radiographic index of lung injury and lower levels of lung derived inflammatory cytokines [63].

Targeting component processes of ALI other than inflammation, tissue injury and VALI should be developed and incentive for this will be greatly increased as novel therapeutics are introduced (Figure 1). We believe that advances in the understanding and treatment of pulmonary fibrosis combined with the relative chronicity of this process complicating ALI, which leads to patients with a low pulmonary compliance struggling to wean from ventilatory support, make this process suitable for targeted intervention. For example, the significance of the epithelial cell integrin alpha-v beta- 6 in activating transforming growth factor beta-1 (TGF $\beta-1$ ) both in the evolution of ALI and repair by fibrosis has only recently been appreciated $[64,65]$. Supposing an effective means of targeting this pathway existed, how could the decision to administer a novel therapy be informed using biomarkers? Patients who are susceptible to or have overactivity of this pathway may be identified using a genomic approach or by identifying a biomarker that is either specific to this process or a damaging fibrotic response. Indeed, the feasibility of this approach has been illustrated by the observation that elevated levels of procollagen peptide III in lavage fluid from patients on Day 3 of ARDS were independent risk factors for mortality [66]. This so-called personalized approach has been pioneered in other chronic lung diseases but the principles are theoretically applicable to ALI [67].

\section{Conclusions}

Biomarker development for patients with ALI is an essential component of progress in translational medicine in this challenging area. Potential pitfalls on the road to successfully carrying out translational medicine to help patients with ALI include:

1. the heterogeneity of cases (ALI is a syndrome resulting from any cause of acute lung failure),

2. the large iatrogenic contribution to pathogenesis, rendering standardization of care crucial,

3. the gas exchange surface of the lung is relatively inaccessible to investigation and indispensible, so that pathogenic process are not well understood, and

4. the timeframes of the condition are short, such that windows for intervention may close in the time that it takes to analyse samples and process data.

Biomarkers should be sensitive and specific indicators of clinically important processes and should change in a relevant timeframe to affect recruitment to trials or clinical management. They do not necessarily need to reflect pathogenic processes. Combining biomarkers with physiological and other data may add predictive power and stimulate the development of important aids to research and therapy. While biomarkers have not yet had a major role in the management of ALI and the development of novel therapies, it is possible and even likely that biomarkers will be developed that will help to target an increasing arsenal of disease modifying therapies in the future.

\section{Abbreviations}

ALI: acute lung injury; ARDS: Acute Respiratory Distress Syndrome; BAL: broncho-alveolar lavage; $\mathrm{ECCO}_{2} \mathrm{R}$ : extra-corporeal carbon dioxide removal; OLV: one lung ventilation; PCT: procalcitonin; SIRS: Systemic Inflammatory Response Syndrome; sTNFR: soluble tumour necrosis factor-alpha receptors; TGF $\beta-1$ : transforming growth factor beta-1; VALI: ventilator associated lung injury.

\section{Acknowledgements}

This work was funded and supported by the NIHR Respiratory Disease Biomedical Research Unit at the Royal Brompton and Harefield NHS Foundation Trust and Imperial College London. The views expressed in this publication are those of the authors and not necessarily those of the NHS, the National Institute for Health Research or the Department of Health.

\section{Author details}

${ }^{1}$ Royal Brompton \& Harefield NHS Foundation Trust, Adult Intensive Care Unit, Sydney Street, London SW3 6NP, UK. ${ }^{2}$ Unit of Critical Care, National Heart and Lung Institute, Imperial College London, London SW3 6LY, UK.

\section{Authors' contributions}

All authors contributed equally to the inception and execution of this article and read and approved the final manuscript.

\section{Competing interests}

MG received consultancy fees, educational grants and served on advisory boards for GlaxoSmithKline (Middlesex, UK). AP and MH have not disclosed any potential conflicts of interest.

Received: 16 August 2011 Accepted: 12 December 2011

Published: 12 December 2011 


\section{References}

1. Bernard GR, Artigas A, Brigham KL, Carlet J, Falke K, Hudson L, Lamy M, Legall JR, Morris A, Spragg R: The American-European Consensus Conference on ARDS. Definitions, mechanisms, relevant outcomes, and clinical trial coordination. Am J Respir Crit Care Med 1994, 149:818-824.

2. Rubenfeld GD, Caldwell E, Peabody E, Weaver J, Martin DP, Neff M, Stern EJ, Hudson LD: Incidence and outcomes of acute lung injury. N Engl J Med 2005, 353:1685-1693.

3. Cheung AM, Tansey CM, Tomlinson G, Diaz-Granados N, Matte A, Barr A Mehta S, Mazer CD, Guest CB, Stewart TE, Al-Saidi F, Cooper AB, Cook D, Slutsky AS, Herridge MS: Two-year outcomes, health care use, and costs of survivors of acute respiratory distress syndrome. Am J Respir Crit Care Med 2006, 174:538-544.

4. Proudfoot AG, McAuley DF, Hind M, Griffiths MJ: Translational research: what does it mean, what has it delivered and what might it deliver? Curr Opin Crit Care 2011, 17:495-503.

5. Cross LJ, Matthay MA: Biomarkers in acute lung injury: insights into the pathogenesis of acute lung injury. Crit Care Clin 2011, 27:355-377.

6. Frank JA, Parsons PE, Matthay MA: Pathogenetic significance of biological markers of ventilator-associated lung injury in experimental and clinical studies. Chest 2006, 130:1906-1914.

7. Gregory TJ, Longmore WJ, Moxley MA, Whitsett JA, Reed CR, Fowler AA, Hudson LD, Maunder RJ, Crim C, Hyers TM: Surfactant chemical composition and biophysical activity in acute respiratory distress syndrome. J Clin Invest 1991, 88:1976-1981.

8. Dantzker DR, Brook CJ, Dehart P, Lynch JP, Weg JG: Ventilation-perfusion distributions in the adult respiratory distress syndrome. Am Rev Respir Dis 1979, 120:1039-1052.

9. Nuckton TJ, Alonso JA, Kallet RH, Daniel BM, Pittet JF, Eisner MD, Matthay MA: Pulmonary dead-space fraction as a risk factor for death in the acute respiratory distress syndrome. N Engl J Med 2002, 346:1281-1286.

10. Christie JD, Ma SF, Aplenc R, Li M, Lanken PN, Shah CV, Fuchs B, Albelda SM, Flores C, Garcia JG: Variation in the myosin light chain kinase gene is associated with development of acute lung injury after major trauma. Crit Care Med 2008, 36:2794-2800.

11. Marshall RP, Webb S, Bellingan GJ, Montgomery HE, Chaudhari B, McAnulty RJ, Humphries SE, Hill MR, Laurent GJ: Angiotensin converting enzyme insertion/deletion polymorphism is associated with susceptibility and outcome in acute respiratory distress syndrome. Am J Respir Crit Care Med 2002, 166:646-650.

12. Moss M, Bucher B, Moore FA, Moore EE, Parsons PE: The role of chronic alcohol abuse in the development of acute respiratory distress syndrome in adults. JAMA 1996, 275:50-54.

13. Moss M, Guidot DM, Steinberg KP, Duhon GF, Treece $P$, Wolken $R$ Hudson LD, Parsons PE: Diabetic patients have a decreased incidence of acute respiratory distress syndrome [see comments]. Crit Care Med 2000, 28:2187-2192.

14. Rocco PR, Zin WA: Pulmonary and extrapulmonary acute respiratory distress syndrome: are they different? Curr Opin Crit Care 2005, 11:10-17.

15. Martin C, Papazian L, Payan MJ, Saux P, Gouin F: Pulmonary fibrosis correlates with outcome in adult respiratory distress syndrome. A study in mechanically ventilated patients [see comments]. Chest 1995, 107:196-200.

16. Dos Santos CC: Advances in mechanisms of repair and remodelling in acute lung injury. Intensive Care Med 2008, 34:619-630.

17. Pratt PC, Vollmer RT, Shelburne JD, Crapo JD: Pulmonary morphology in a multihospital collaborative extracorporeal membrane oxygenation project. I. Light microscopy. Am J Pathol 1979, 95:191-214.

18. Chesnutt AN, Matthay MA, Tibayan FA, Clark JG: Early detection of type III procollagen peptide in acute lung injury. Pathogenetic and prognostic significance. Am J Respir Crit Care Med 1997, 156:840-845.

19. Owens CM, Evans TW, Keogh BF, Hansell DM: Computed tomography in established adult respiratory distress syndrome. Correlation with lung injury score. Chest 1994, 106:1815-1821.

20. Quesnel C, Nardelli L, Piednoir P, Lecon V, Marchal-Somme J, Lasocki S, Bouadma L, Philip I, Soler P, Crestani B, Dehoux M: Alveolar fibroblasts in acute lung injury: biological behaviour and clinical relevance. Eur Respir $J$ 2010, 35:1312-1321.

21. Kaminski N, Allard JD, Pittet JF, Zuo F, Griffiths MJ, Morris D, Huang X, Sheppard D, Heller RA: Global analysis of gene expression in pulmonary fibrosis reveals distinct programs regulating lung inflammation and fibrosis. Proc Natl Acad Sci USA 2000, 97:1778-1783.

22. Crosby LM, Waters CM: Epithelial repair mechanisms in the lung. Am J Physiol Lung Cell Mol Physiol 2010, 298:L715-731.

23. Network TARDS: Ventilation with lower tidal volumes as compared with traditional tidal volumes for acute lung injury and the acute respiratory distress syndrome. N Engl J Med 2000, 342:1301-1308.

24. Wiedemann HP, Wheeler AP, Bernard GR, Thompson BT, Hayden D, deBoisblanc B, Connors AF Jr, Hite RD, Harabin AL: Comparison of two fluid-management strategies in acute lung injury. N Engl J Med 2006, 354:2564-2575.

25. McAuley DF, O'Kane C, Griffiths MJ: A stepwise approach to justify phase III randomized clinical trials and enhance the likelihood of a positive result. Crit Care Med 2010, 38:S523-527.

26. Determann RM, Royakkers A, Wolthuis EK, Vlaar AP, Choi G, Paulus F, Hofstra JJ, de Graaff MJ, Korevaar JC, Schultz MJ: Ventilation with lower tidal volumes as compared with conventional tidal volumes for patients without acute lung injury: a preventive randomized controlled trial. Crit Care 2010, 14:R1

27. Villar J, Slutsky AS: Is acute respiratory distress syndrome an iatrogenic disease? Crit Care 2010, 14:120

28. Yilmaz M, Keegan MT, Iscimen R, Afessa B, Buck CF, Hubmayr RD, Gajic O: Toward the prevention of acute lung injury: protocol-guided limitation of large tidal volume ventilation and inappropriate transfusion. Crit Care Med 2007, 35:1660-1666, quiz 1667.

29. Khan H, Belsher J, Yilmaz M, Afessa B, Winters JL, Moore SB, Hubmayr RD, Gajic O: Fresh-frozen plasma and platelet transfusions are associated with development of acute lung injury in critically ill medical patients. Chest 2007, 131:1308-1314

30. Li G, Malinchoc M, Cartin-Ceba R, Venkata CV, Kor DJ, Peters SG, Hubmayr RD, Gajic O: Eight-year trend of acute respiratory distress syndrome: a population-based study in Olmsted County, Minnesota. Am J Respir Crit Care Med 2011, 183:59-66.

31. Young MP, Manning HL, Wilson DL, Mette SA, Riker RR, Leiter JC, Liu SK, Bates JT, Parsons PE: Ventilation of patients with acute lung injury and acute respiratory distress syndrome: has new evidence changed clinical practice? Crit Care Med 2004, 32:1260-1265.

32. Bouadma L, Luyt CE, Tubach F, Cracco C, Alvarez A, Schwebel C, Schortgen F, Lasocki S, Veber B, Dehoux M, Bernard M, Pasquet B, Regnier B, Brun-Buisson C, Chastre J, Wolff M: Use of procalcitonin to reduce patients' exposure to antibiotics in intensive care units (PRORATA trial): a multicentre randomised controlled trial. Lancet 2010, 375:463-474.

33. Karlsson S, Heikkinen M, Pettila V, Alila S, Vaisanen S, Pulkki K, Kolho E, Ruokonen E: Predictive value of procalcitonin decrease in patients with severe sepsis: a prospective observational study. Crit Care 2010, 14:R205.

34. Clec'h C, Ferriere F, Karoubi P, Fosse JP, Cupa M, Hoang P, Cohen Y: Diagnostic and prognostic value of procalcitonin in patients with septic shock. Crit Care Med 2004, 32:1166-1169.

35. Luyt CE, Combes A, Trouillet $J$, Chastre J: Value of the serum procalcitonin level to guide antimicrobial therapy for patients with ventilator-associated pneumonia. Semin Respir Crit Care Med 2011, 32:181-187.

36. Perkins GD, McAuley DF, Thickett DR, Gao F: The beta-agonist lung injury trial (BALTI): a randomized placebo-controlled clinical trial. Am J Respir Crit Care Med 2006, 173:281-287.

37. Sakka SG, Klein M, Reinhart K, Meier-Hellmann A: Prognostic value of extravascular lung water in critically ill patients. Chest 2002, 122:2080-2086.

38. Craig TR, Duffy MJ, Shyamsundar M, McDowell C, McLaughlin B, Elborn JS, McAuley DF: Extravascular lung water indexed to predicted body weight is a novel predictor of intensive care unit mortality in patients with acute lung injury. Crit Care Med 2010, 38:114-120.

39. Phillips CR, Chesnutt MS, Smith SM: Extravascular lung water in sepsisassociated acute respiratory distress syndrome: indexing with predicted body weight improves correlation with severity of illness and survival. Crit Care Med 2008, 36:69-73.

40. Estenssoro E, Dubin A, Laffaire E, Canales H, Saenz G, Moseinco M, Pozo M, Gomez A, Baredes N, Jannello G, Osatnik J: Incidence, clinical course, and outcome in 217 patients with acute respiratory distress syndrome. Crit Care Med 2002, 30:2450-2456. 
41. Cooke CR, Shah CV, Gallop R, Bellamy S, Ancukiewicz M, Eisner MD, Lanken PN, Localio AR, Christie JD: A simple clinical predictive index for objective estimates of mortality in acute lung injury. Crit Care Med 2009, 37:1913-1920

42. Cooke CR, Kahn JM, Caldwell E, Okamoto VN, Heckbert SR, Hudson LD, Rubenfeld GD: Predictors of hospital mortality in a population-based cohort of patients with acute lung injury. Crit Care Med 2008, 36:1412-1420.

43. Bucher HC, Guyatt GH, Cook DJ, Holbrook A, McAlister FA: Users' guides to the medical literature: XIX. Applying clinical trial results. A. How to use an article measuring the effect of an intervention on surrogate end points. Evidence-Based Medicine Working Group. JAMA 1999, 282:771-778.

44. Parsons PE, Matthay MA, Ware LB, Eisner MD: Elevated plasma levels of soluble TNF receptors are associated with morbidity and mortality in patients with acute lung injury. Am J Physiol Lung Cell Mol Physiol 2005, 288:L426-431.

45. Calfee CS, Eisner MD, Parsons PE, Thompson BT, Conner ER Jr, Matthay MA, Ware LB: Soluble intercellular adhesion molecule- 1 and clinical outcomes in patients with acute lung injury. Intensive Care Med 2009, 35:248-257.

46. Parsons PE, Eisner MD, Thompson BT, Matthay MA, Ancukiewicz M, Bernard GR, Wheeler AP: Lower tidal volume ventilation and plasma cytokine markers of inflammation in patients with acute lung injury. Crit Care Med 2005, 33:1-6, discussion 230-232

47. Calfee CS, Ware LB, Eisner MD, Parsons PE, Thompson BT, Wickersham N, Matthay MA, NHLBI ARDS Network: Plasma receptor for advanced glycation end-products and clinical outcomes in acute lung injury. Thorax 2008, 63:1083-1089.

48. Eisner MD, Parsons P, Matthay MA, Ware L, Greene K: Plasma surfactant protein levels and clinical outcomes in patients with acute lung injury. Thorax 2003, 58:983-988.

49. Ware LB, Matthay MA, Parsons PE, Thompson BT, Januzzi JL, Eisner MD: Pathogenetic and prognostic significance of altered coagulation and fibrinolysis in acute lung injury/acute respiratory distress syndrome. Crit Care Med 2007, 35:1821-1828

50. Tremblay LN, Slutsky AS: Ventilator-induced injury: from barotrauma to biotrauma. Proc Assoc Am Physicians 1998, 110:482-488.

51. Calfee CS, Ware LB, Glidden DV, Eisner MD, Parsons PE, Thompson BT, Matthay MA, National Heart, Blood, and Lung Institute Acute Respiratory Distress Syndrome Network: Use of risk reclassification with multiple biomarkers improves mortality prediction in acute lung injury. Crit Care Med 2011, 39:711-717.

52. Ware LB, Koyama T, Billheimer DD, Wu W, Bernard GR, Thompson BT, Brower RG, Standiford TJ, Martin TR, Matthay MA: Prognostic and pathogenetic value of combining clinical and biochemical indices in patients with acute lung injury. Chest 2010, 137:288-296.

53. Proudfoot AG, McAuley DF, Griffiths MJ, Hind M: Human models of acute lung injury. Dis Model Mech 2011, 4:145-153.

54. Bastarache JA, Blackwell TS: Development of animal models for the acute respiratory distress syndrome. Dis Model Mech 2009, 2:218-223.

55. Gharib SA, Nguyen E, Altemeier WA, Shaffer SA, Doneanu CE, Goodlett DR, Schnapp LM: Of mice and men: comparative proteomics of bronchoalveolar fluid. Eur Respir J 2010, 35:1388-1395.

56. Bastin AJ, Sato H, Davidson SJ, Quinlan GJ, Griffiths MJ: Biomarkers of lung injury after one-lung ventilation for lung resection. Respirology 2011 16:138-145.

57. Moloney ED, Griffiths MJ: Protective ventilation of patients with acute respiratory distress syndrome. $\mathrm{Br} J$ Anaesth 2004, 92:261-270.

58. van der Werff YD, van der Houwen HK, Heijmans PJ, Duurkens VA, Leusink HA, van Heesewijk HP, de Boer A: Postpneumonectomy pulmonary edema. A retrospective analysis of incidence and possible risk factors. Chest 1997, 111:1278-1284.

59. Licker M, Diaper J, Villiger Y, Spiliopoulos A, Licker V, Robert J, Tschopp JM Impact of intraoperative lung-protective interventions in patients undergoing lung cancer surgery. Crit Care 2009, 13:R41.

60. Schilling T, Kozian A, Huth C, Buhling F, Kretzschmar M, Welte T, Hachenberg $T$ : The pulmonary immune effects of mechanical ventilation in patients undergoing thoracic surgery. Anesth Analg 2005, 101:957-965.

61. Spragg RG, Bernard GR, Checkley W, Curtis JR, Gajic O, Guyatt G, Hall J, Israel E, Jain M, Needham DM, Randolph AG, Rubenfeld GD, Schoenfeld D, Thompson BT, Ware LB, Young D, Harabin AL: Beyond mortality: future clinical research in acute lung injury. Am J Respir Crit Care Med 2010, 181:1121-1127.

62. Terragni PP, Rosboch G, Tealdi A, Corno E, Menaldo E, Davini O, Gandini G, Herrmann P, Mascia L, Quintel M, Slutsky AS, Gattinoni L, Ranieri VM: Tidal hyperinflation during low tidal volume ventilation in acute respiratory distress syndrome. Am J Respir Crit Care Med 2007, 175:160-166.

63. Terragni PP, Del Sorbo L, Mascia L, Urbino R, Martin EL, Birocco A, Faggiano C, Quintel M, Gattinoni L, Ranieri VM: Tidal volume lower than 6 $\mathrm{ml} / \mathrm{kg}$ enhances lung protection: role of extracorporeal carbon dioxide removal. Anesthesiology 2009, 111:826-835.

64. Munger JS, Harpel JG, Giancotti FG, Rifkin DB: Interactions between growth factors and integrins: latent forms of transforming growth factor-beta are ligands for the integrin alphavbeta1. Mol Biol Cell 1998, 9:2627-2638

65. Pittet JF, Griffiths MJ, Geiser T, Kaminski N, Dalton SL, Huang X, Brown LA, Gotwals PJ, Koteliansky VE, Matthay MA, Sheppard D: TGF-beta is a critical mediator of acute lung injury. J Clin Invest 2001, 107:1537-1544.

66. Clark JG, Milberg JA, Steinberg KP, Hudson LD: Type III procollagen peptide in the adult respiratory distress syndrome. Association of increased peptide levels in bronchoalveolar lavage fluid with increased risk for death. Ann Intern Med 1995, 122:17-23.

67. Lynch TJ, Bell DW, Sordella R, Gurubhagavatula S, Okimoto RA, Brannigan BW, Harris PL, Haserlat SM, Supko JG, Haluska FG, Louis DN, Christiani DC, Settleman J, Haber DA: Activating mutations in the epidermal growth factor receptor underlying responsiveness of nonsmall-cell lung cancer to gefitinib. N Engl J Med 2004, 350:2129-2139.

\section{Pre-publication history}

The pre-publication history for this paper can be accessed here: http://www.biomedcentral.com/1741-7015/9/132/prepub

doi:10.1186/1741-7015-9-132

Cite this article as: Proudfoot et al:: Biomarkers of acute lung injury: worth their salt? BMC Medicine 2011 9:132.

\section{Submit your next manuscript to BioMed Central and take full advantage of:}

- Convenient online submission

- Thorough peer review

- No space constraints or color figure charges

- Immediate publication on acceptance

- Inclusion in PubMed, CAS, Scopus and Google Scholar

- Research which is freely available for redistribution

Submit your manuscript at www.biomedcentral.com/submit
C Biomed Central 